\title{
ФОРМУВАННЯ НАУКОВО-ДОСЛІДНОЇ КОМПЕТЕНТНОСТІ В МАЙБУТНІХ ІНЖЕНЕРІВ-ТЕХНОЛОГІВ
}

\author{
Лазарсва Т. А \\ доктор педагогічних наук, професор, \\ професор кафедри харчових та хімічних технологій \\ Українська інженерно-педагогічна академія \\ вул. Університетська, 16, Харків, Украӥна \\ orcid.org/0000-0003-4435-3345 \\ Lazareva_T.A@ukr.net \\ Лазарсв М. I. \\ доктор педагогічних наук, професор, \\ професор кафедри креативної педагогіки та інтелектуальної власності \\ Українська інженерно-педагогічна академія \\ вул. Університетська, 16, Харків, Україна \\ orcid.org/0000-0001-9742-4739
}

\begin{abstract}
Ключові слова:
харчова галузь, науководослідна діяльність, інженертехнолог, компетентність, знання, уміння, навички, професійно важливі якості, особистісні здібності, досвід.
\end{abstract}

У статті доведено визначальну роль формування науково-дослідної компетентності в майбутніх інженерів-технологів харчової галузі для перспективного розвитку підприємства, виходу його на міжнародні ринки збуту продукції, розширення асортименту харчової продукції, впровадження інноваційних технологій та обладнання. Виявлено, що професійна компетентність фахівця являє собою конгломерат знань, умінь, навичок, професійно важливих якостей, особистісних здібностей та досвіду, формування яких визначає кваліфікаційний рівень фахівця. Визначено, що для виконання науково-дослідної діяльності інженерутехнологу важливо оперувати сучасними знаннями 3 різних наукових галузей, мати широкий кругозір, володіти прийомами розв'язування творчих задач. Формування умінь у майбутніх інженерів-технологів харчової галузі має здійснюватися на рівнях впізнання інформації, іiі репродуктивного, продуктивного та творчого застосування. Виділено професійно важливі якості інженера-технолога, які варто формувати у студентів із метою належного виконання науково-дослідної діяльності. Встановлено такі мотиваційно-цільові професійно важливі якості, як цілеспрямованість, захопленість, творча активність, прагнення до успіху у творчій професійній діяльності, наполегливість. До блоку когнітивних якостей зараховано сенсорно-перцептивні, мнемічні якості, представлення, творчу уяву, творче мислення, увагу. Не менш важливими $\epsilon$ світоглядні професійно важливі якості: чесність, відповідальність, гуманність. Для виконання науково-дослідної діяльності також треба розвивати особисто- та соціально-діяльнісні якості. Однією із складових частин професійної компетентності майбутнього фахівця харчової галузі $\epsilon$ такі особистісні здібності, як індивідуальний творчий стиль діяльності, самоаналіз, саморегулювання, самоуправління та самооцінювання. Виконання квазіпрофесійної навчальної діяльності у процесі розв'язання професійно орієнтованих задач дає змогу формувати в майбутніх інженерів-технологів досвід творчої діяльності щодо розробки та удосконалення харчових продуктів, технологій та обладнання. 


\title{
THE FORMATION OF THE RESEARCH COMPETENCE OF FUTURE ENGINEERS-TECHNOLOGISTS
}

\author{
Lazarieva T. A. \\ Doctor of Pedagogical Sciences, Professor, \\ Professor at the Department of Food and Chemical Technology \\ Ukrainian Engineering-Pedagogics Academy \\ Universitetskaya str., 16, Kharkiv, Ukraine \\ orcid.org/0000-0003-4435-3345 \\ Lazareva_T.A@ukr.net \\ Lazariev M. I. \\ Doctor of Pedagogical Sciences, Professor, \\ Professor at the Department of Creative Education and Intellectual Property \\ Ukrainian Engineering-Pedagogics Academy \\ Universitetskaya str., 16, Kharkiv, Ukraine \\ orcid.org/0000-0001-9742-4739
}

Key words:

food industry, research activity, technological engineer, competence, knowledge, skills, abilities, professionally important qualities, personal abilities, experience.
The article proves the decisive role of formation of research competence in future engineers-technologists of the food industry for the long-term development of the enterprise, its entry into international markets, expanding the range of food products, introduction of innovative technologies and equipment. It is revealed that the professional competence of a specialist is a conglomeration of knowledge, skills, abilities, professionally important qualities, personal abilities and experience. It is determined that in order to perform research activities, it is important for a technological engineer to operate with modern knowledge from various scientific fields, to have a broad outlook, to have techniques for solving creative problems. The formation of skills in future engineers-technologists of the food industry should be carried out at the levels of information recognition, its reproductive, productive and creative application. The professionally important qualities of the engineer-technologist which should be formed at students for the purpose of proper performance of research activity are allocated. Motivational and targeted professionally important qualities such as purposefulness, enthusiasm, creative activity, desire to succeed in creative professional activity, persistence have been established. The block of cognitive qualities includes sensory-perceptual, mnemonic qualities, representation and creative imagination, creative thinking, attention. No less important are worldview professionally important qualities such as honesty, responsibility, humanity. To perform research activities should also develop personal and social activities. One of the components of the professional competence of the future food industry specialist is such personal abilities as individual creative style of activity, self-analysis, self-regulation, self-management and selfevaluation. Execution of quasi-professional educational activities in solving professionally oriented tasks allows to form in future engineers-technologists the experience of creative activity on development and improvement of food products, technologies and equipment.
Постановка проблеми. Сучасний розвиток підприємств харчової галузі, конкурентна боротьба за споживача, нові можливості виходу харчової продукції підприємств на міжнародні ринки вимагають постійного розширення асортименту продукції, удосконалення технологій виробництва, впровадження новітнього обладнання. У таких складних умовах більш жорсткими стають вимоги до кваліфікаційного рівня інженера-технолога харчової галузі, який повинен мати сформовані компетентності науково-дослідної діяльності. У зв’ язку з цим перед закладами вищої 
освіти, які здійснюють професійну підготовку майбутніх інженерних кадрів, постає завдання надання їм відповідних знань, формування умінь, навичок та професійно важливих якостей.

Метою статті $\epsilon$ аналіз науково-дослідної діяльності фахівців харчової галузі, встановлення знань, умінь, навичок та професійно важливих якостей, визначення цілей, змісту навчання для формування науково-дослідної компетентності майбутніх інженерів-технологів харчової галузі.

Виклад основного матеріалу дослідження. Сучасна діяльність підприємств харчової галузі зосереджена на розширенні асортименту харчової продукції, впровадженні інноваційних технологій та обладнання, розширенні та виходу продукції підприємства на міжнародні ринки. У таких умовах розвиток підприємства залежить від науково-дослідної діяльності інженерів-технологів. Їх діяльність спрямована на пошук нової сировини, матеріалів, ідей, творче перетворення, вирішення нестандартних завдань у виробництві продукції, що зумовлено сформованою науково-дослідною компетентністю.

Визначимо, як реалізується науково-дослідна діяльність інженера-технолога. 3 проведеного аналізу робіт [1-5] визначено, що майбутній інженер-технолог має знати:

- вітчизняний та міжнародний досвід щодо організації та проведення науково-дослідних робіт у харчовій галузі;

- вітчизняні і світові досягнення та перспективні напрями щодо розробки інноваційних харчових продуктів, технологій та обладнання;

- характеристики, властивості, критерії, параметри, показники якості та методи дослідження традиційних та інноваційних видів сировини, напівфабрикатів та харчових продуктів;

- послідовність стадій, операцій, дій, критерії, параметри традиційних та інноваційних харчових технологій;

- призначення, склад, конструкцію, механізм та принцип дії, умови монтажу та експлуатації, критеpiї та параметри, методи дослідження традиційного та інноваційного технологічного обладнання;

- ресурси спеціальної науково-технічної і патентної літератури 3 тематики досліджень і розробок;

- порядок користування реферативними i довідково-інформаційними виданнями, а також іншими джерелами науково-технічної інформації;

- стандарти, технічні умови та інші керівні матеріали щодо розроблення і оформлення технічної документації у процесі виконання науково-дослідної роботи;

- порядок та методи проведення патентних досліджень, основи винахідництва та раціоналізаторства;
- сучасні методи, засоби планування, організації, проведення наукових досліджень, порядок проведення досліджень, випробувань, спостережень;

- методи і засоби виконання технічних розрахунків і обчислювальних робіт, методи аналізу та перевірки адекватності результатів дослідження;

- порядок оформлення науково-технічної документаціі;

- порядок складання заявок на винаходи, корисні моделі та інші об'єкти інтелектуальної власності;

- вимоги до організації праці в процесі проведення наукових досліджень;

- правила техніки безпеки, виробничої санітаpiï, протипожежної безпеки у процесі виконання науково-дослідних робіт.

Визначимо перелік умінь, які необхідно формувати у процесі професійної підготовки майбутнього інженера-технолога до науково-дослідної діяльності щодо розробки та удосконалення харчових продуктів, технологій та обладнання. 3 проведеного аналізу робіт [7-10] встановлено, що майбутній інженер-технолог на рівні впізнання інформації має вміти:

- вибирати необхідний матеріал, контрольно-вимірювальні прилади, інструменти та обладнання для проведення наукових досліджень;

- здійснювати спостереження та вимірювання під час проведення досліджень;

- фіксувати результати вимірювань, випробувань, спостережень, досліджень;

- здійснювати контроль за станом і правильним користуванням приладів, обладнання, апаратури, що використовується;

- працювати з різними джерелами інформації (навчальною, науково-методичною, технічною літературою та ін.);

На рівні репродуктивного застосування необхідно формувати у студентів такі уміння:

- вибирати методи проведення досліджень, випробувань та спостережень;

- налагоджувати прилади, обладнання, апаратуру для проведення досліджень, випробувань, спостережень;

- проводити наукові дослідження, випробування, спостереження;

- обирати методи математичного аналізу даних досліджень;

- проводити необхідні розрахунки за визначеними методиками;

- порівнювати результати досліджень, випробувань, спостережень.

Майбутній інженер-технолог на рівні продуктивного застосування навчальної інформації має уміти:

- проводити патентні дослідження; 
- складати установки, стенди для проведення досліджень;

- аналізувати, узагальнювати, класифікувати та систематизувати науково-технічну інформацію за темою завдання;

- складати описи хімічного складу, рецептури харчових продуктів, технологічних етапів виробництва, будови та принципів дії обладнання, що розробляється;

- готувати інформаційні огляди, рецензії, відгуки і висновки на технічну документацію;

- аналізувати результати досліджень, випробувань та спостережень;

- аналізувати результати розрахунків.

Особливо важливим для майбутнього інженера-технолога стає формування умінь на рівні творчого застосування:

- визначати, формулювати нові напрямки досліджень та розробок;

- визначати протиріччя, мету дослідження, висувати гіпотезу та встановлювати завдання дослідження;

- обгрунтовувати, планувати та розробляти етапи та програму науково-дослідних робіт;

- аналізувати, узагальнювати результати досліджень та складати звіти про виконану роботу;

- обгрунтовувати та пропонувати інноваційні харчові продукти, технології та обладнання;

- здійснювати впровадження результатів досліджень у виробництво;

- розробляти нормативну та технічну документацію на нові об'єкти: продукти, технологію, обладнання;

- складати заявки на винаходи та відкриття.

Визначимо професійно важливі якості науково-дослідної компетентності, які необхідно формувати в майбутнього інженера-технолога у процесі професійної підготовки (рис. 1) [11-13].

Обгрунтуємо складники блоку мотиваційно-цільових професійно важливих якостей. Науково-дослідна діяльність інженера-технолога 3 розробки та вдосконалення об'єктів харчової галузі - це цілеспрямована, наполеглива, творча робота, що зумовлена появою інтересу до пізнання нових фактів, явищ, відношень, зв'язків, закономірностей та ін., потребою вирішувати поставлене завдання, зробити важливе для суспільства відкриття, досягти успіху. Професійна науково-дослідна діяльність інженера-технолога зумовлюється рівнем сформованості мотивації. Тому необхідно формувати в майбутнього інженера-технолога такі мотиваційно-цільові професійно важливі якості, як цілеспрямованість, захопленість, творча активність, прагнення до успіху у творчій професійній діяльності, наполегливість.

Розглянемо блок когнітивних професійно важливих якостей [11-13]. У науково-дослідній діяльності інженера-технолога професійно важливими $\epsilon$ сенсорно-перцептивні якості.

Дослідження інноваційних видів сировини, речовини, матеріалів, напівфабрикатів та харчових продуктів здійснюється за такими показниками, як зовнішній вигляд, смак, запах, консистенція. У дослідженні інноваційного обладнання звертають увагу на стан поверхні робочих органів, який може бути гладким, ребристим, зубчастим та ін. У роботі обладнання помічають наявність шуму, вібрацій, зміни кольору сигнальних ламп, наявність попереджуючих сигнальних звуків, температурні зміни та ін. У процесі розробки та дослідження інноваційних технологій виробництва харчових продуктів важливим є сприйняття часу проведення окремих операцій та дій, напрям потоків сировини, матеріалів, напівфабрикатів та готової продукції у просторі цеху, ділянки, підрозділу. Таким чином, у професійній підготовці майбутнього інженера-технолога до науково-дослідної діяльності необхідним є формування професійно важливих якостей відчуття та сприйняття.

У науково-дослідній діяльності інженера-технолога окрему роль відіграють мнемонічні професійно важливі якості. Проведення значної кількості дослідів, спостережень, порівняння результатів аналізу сировини, матеріалів, продуктів, технологій та обладнання вимагає від інженера-технолога утримання значних обсягів інформації, зберігання іiі та відтворення.

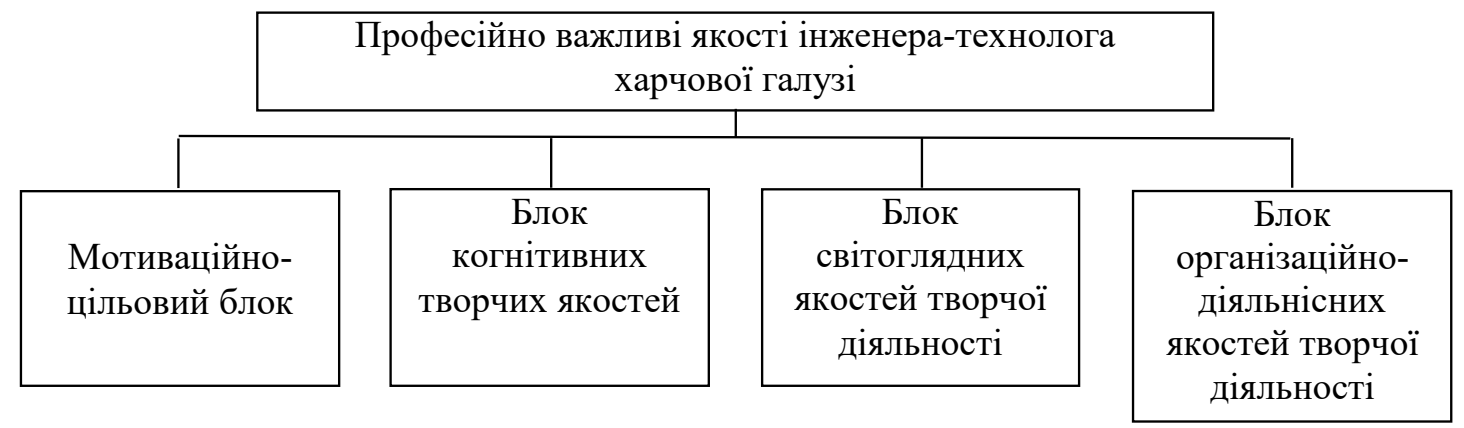

Рис. 1. Структура професійно важливих якостей інженера-технолога харчової галузі 
Не менш важливими для науково-дослідної діяльності інженера-технолога є розвинуті професійно важливі якості представлення та творчої уяви. У процесі дослідження об'єктів харчової галузі інженер-технолог проводить хімічні, фізичні, механічні, температурні випробування сировини, речовин, матеріалів, напівфабрикатів та продуктів. Внаслідок таких дослідів відбуваються зміни. Інженеру-технологу необхідно представити та уявити механізм процесів, причини та наслідки.

У науково-дослідній діяльності проявляються професійно важливі якості творчого мислення $[8 ; 10]$. У такій діяльності задіяні наочно-ді$€ в е$, наочно-образне та словесно-логічне мислення. У дослідженні об'єктів харчової галузі інженер-технолог цілісно та системно сприймає інформацію, критично іiі аналізує, визначає проблему розробки та вдосконалення об'єктів, висуває гіпотезу, розробляє план проведення дослідів, спостережень, випробувань, проводить розрахунки, аналізує їх, узагальнюе та робить висновки. Суттєвими для інженера-технолога $\epsilon$ цілісність мислення, аналітичність, системність та критичність мислення, креативність, оригінальність та нестандартність. Розвиток мислення як професійно важливої якості проявляється у винахідливості, здатності до сприйняття нетипової інформації, здатності до алгоритмізації розумових процесів та абстрагуванні, здатності до творчої фантазії.

Значну роль у науково-дослідній діяльності відіграють розвинуті професійно важливі якості уваги. Розробляючи та вдосконалюючи об'єкти харчової галузі, інженер-технолог проводить спостереження за значною кількістю змінних параметрів, визначає незначні зміни в об'єктів спостереження, зосереджується на головних показниках та параметрах об'єктів, швидко орієнтується у ситуаціях, які змінюються.

3 аналізу науково-дослідної діяльності визначаємо, що у професійній підготовці майбутнього інженера-технолога необхідно розвивати та формувати когнітивні професійно важливі якості відчуття, сприйняття, пам'яті, представлення, уяви, мислення та уваги.

Розглянемо блок світоглядних професійно важливих якостей інженера-технолога в науково-дослідній діяльності. Необхідною умовою дослідження об'єктів харчової галузі є чесність у визначенні позитивних та негативних результатів дослідів, сумлінне виконання спостережень, відповідальність за свої рішення та дії щодо удосконалення продуктів, технології та обладнання, свідоме гуманне ставлення до людства в процесі впровадження та дослідження інноваційних видів сировини, речовин, матеріалів та ін., турбота за стан навколишнього середовища у процесі розробки технологій виробництва продуктів та обладнання, чесне визнання авторських прав на об'єкти інтелектуальної власності. Отже, у процесі професійної підготовки майбутніх інженерів-технологів до науково-дослідної діяльності необхідно формувати визначені світоглядні професійно важливі якості.

Розкриємо зміст організаційно-діяльнісних професійно важливих якостей інженера-технолога. Особисто-діяльнісними професійно важливими якостями інженера-технолога у виконанні науково-дослідних робіт $\epsilon$ організованість у проведенні експериментів та дослідів, дисциплінованість у роботі, старанність та акуратність, скрупульозність під час проведення розрахунків та обробки результатів, ініціативність та винахідливість у вирішенні виробничих проблем, планомірність та методичність на всіх етапах дослідження об'єктів, раціональність та практичність у визначенні кінцевих результатів досліджень, терпеливість у проведенні значної кількості дослідів та спостережень, допитливість у пошуку ідей, самостійність, самокритичність, здатність до неперервного саморозвитку та самовдосконалення [14].

Соціально-діяльнісні професійно важливі якості в науково-дослідній діяльності інженера-технолога проявляються у процесі колективного розв'язування виробничих задач, поділу завдань між колегами, сумісному проведенні дослідів, спостережень, анкетувань, тестувань та обговоренні результатів, організації та проведенні нарад, наукових конференцій та симпозіумів для обміну науковим досвідом із колегами інших підрозділів, відділів, наукових центрів, доведенні та затвердженні перспективних напрямків розвитку підприємства.

Таким чином, для належного виконання науково-дослідної роботи необхідно в процесі професійної підготовки майбутніх інженерів-технологів розвивати та формувати визначені організаційно-діяльнісні професійно важливі якості.

Професійна компетентність майбутнього фахівця харчової галузі грунтується на таких сформованих особистісних здібностях, як індивідуальний творчий стиль діяльності, самоаналіз, саморегулювання, самоуправління та самооцінювання власної поведінки і творчої діяльності, а також результатів такої діяльності [14]. У процесі квазіпрофесійної діяльності під час розв'язання професійно орієнтованих задач у студентів формується досвід творчої діяльності щодо розробки та удосконалення харчових продуктів, технологій та обладнання. Складники науково-дослідної компетентності майбутнього інженера-технолога харчової галузі представлено у табл. 1. 
Таблиця 1

Складники науково-дослідної компетентності майбутнього інженера-технолога харчової галузі

\begin{tabular}{|c|c|c|c|c|}
\hline $\begin{array}{c}\text { Професійна } \\
\text { компетентність }\end{array}$ & Знання, уміння, навички & $\begin{array}{c}\text { Професійно } \\
\text { важливі якості }\end{array}$ & Особистісні здібності & Досвід \\
\hline Науково-дослідна & $\begin{array}{l}\text { Професійні знання для } \\
\text { виконання науково-дослідної } \\
\text { діяльності } \\
\text { Уміння виконувати науково- } \\
\text { дослідну діяльність на } \\
\text { рівнях: } \\
\text { - впізнання, } \\
- \text { репродуктивному, } \\
- \text { продуктивному, } \\
- \text { творчого застосування }\end{array}$ & $\begin{array}{l}\text { Мотиваційно- } \\
\text { цільові, } \\
\text { когнітивні, } \\
\text { світоглядні } \\
\text { організаційно- } \\
\text { діяльнісні }\end{array}$ & $\begin{array}{c}\text { Індивідуальний твор- } \\
\text { чий стиль діяльності, } \\
\text { самоаналіз, } \\
\text { саморегулювання, } \\
\text { самоуправління, оці- } \\
\text { нювання власної пове- } \\
\text { дінки і науково-дослід- } \\
\text { ної діяльності }\end{array}$ & $\begin{array}{c}\text { Досвід науково- } \\
\text { дослідної діяль- } \\
\text { ності }\end{array}$ \\
\hline
\end{tabular}

Висновки. Отже, перспективний розвиток підприємств харчової галузі, вихід його на міжнародні ринки збуту продукції, розширення асортименту харчової продукції, впровадження інноваційних технологій та обладнання залежать від висококваліфікованої творчої, науково-дослідної професійної діяльності інженерів-технологів. Науковою новизною є виявлення змісту професій- ної компетентності інженера-технолога харчової галузі з науково-дослідної діяльності як системи знань, умінь, навичок, професійно важливих якостей, особистісних здібностей та досвіду.

Перспективами подальших розробок у цьому напрямі є обгрунтування та розробка методу навчання майбутніх інженерів-технологів для виконання науково-дослідної діяльності.

\section{Література}

1. Довідник кваліфікаційних характеристик професій працівників. Випуск 1. Професії працівників, що є загальними для всіх видів економічної діяльності. Розділ 1. Професії керівників, професіоналів, спеціалістів та технічних службовців / Уклад. Я. Кавторєва. Харків : Фактор, 2008. 384 с.

2. Довідник кваліфікаційних характеристик професій працівників. URL: https://dnaop.com/html/ 31666 34.html

3. Кваліфікаційні вимоги. Інженер-дослідник. URL: https://www.borovik.com/index_i.php?Gins=369 \&lang_i=1

4. Державний класифікатор України: Класифікатор професій ДК 003-45. Київ : Держстандарт України, 1995.

5. Лазарєва Т.А. Виробничі функції інженера-технолога харчової галузі як основа формування змісту творчої професійної підготовки. Педагогічні науки: теорія, історія, інноваційні технології. 2013. № 4 (30). С. 237-246.

6. Лазарєва Т.А. Підготовка майбутніх інженерів-технологів харчової галузі до творчої професійної діяльності : монографія. Харків : Право, 2014. 528 с.

7. Гузалова О.В. Педагогічні умови організації творчої діяльності студентів вищих технічних навчальних закладів у процесі вивчення природничо-математичних дисциплін : автореф. дис. ... канд. пед. наук : 13.00.04. Одеса, 2010. 21 с.

8. Еремина Л.И., Нагорнова А.Ю., Нагорнов Ю.С. Технологии креативного развития студентов технических специальностей. Фундаментальные исследования. 2013. № 1. С. 78-81.

9. Нізовцев А.В. Формування дослідницьких умінь студентів технічних університетів у процесі вивчення професійно-орієнтованих дисциплін : автореф. дис. ... канд. пед. наук : 13.00.04. Полтава, 2010. $20 \mathrm{c}$.

10. Попова О.П. Розвиток творчого потенціалу майбутнього інженера в процесі професійної підготовки у вищому технічному навчальному закладі: автореф. дис. .... канд. пед. наук : 13.00.04. Запоріжжя, 2009. 23 c.

11. Лазарєва Т.А. Формування професійно важливих якостей творчої діяльності у майбутніх інженерів-технологів харчової галузі. Проблеми інженерно-педагогічної освіти. 2015. Вип. 46. С. $109-113$.

12. Психологія діяльності та навчальний менеджмент / За заг. ред. В.А. Козакова. Київ : КНЕУ, 2003. 829 c.

13. Шадриков В. Д. Психология деятельности и способности человека. М.: «Логос», 1996. 320 с.

14. Кабанець М.М. Педагогічні умови формування у майбутніх інженерів потреби у творчій самореалізації : автореф. дис. ... канд. пед. наук : 13.00.04. Луганськ, 2010. 20 с. 


\section{References}

1. Kavtorieva, Ya. (ed). (2008) Profesii kerivnykiv, profesionaliv, spetsialistiv ta tekhnichnykh sluzhbovtsiv [Professions of managers, professionals, specialists and technical staff]. Dovidnyk kvalifikatsiinykh kharakterystyk profesii pratsivnykiv [Directory of qualification characteristics of employees' professions]. Kharkiv: Faktor.

2. Dovidnyk kvalifikatsiinykh kharakterystyk profesii pratsivnykiv [Directory of qualification characteristics of employees' professions]. URL: https://dnaop.com/html/31666 34.html (accessed 05 August 2020).

3. Kvalifikatsiini vymohy. Inzhener-doslidnyk [Qualification requirements. Research engineer]. URL: https://www.borovik.com/index_i.php (accessed 07 August 2020).

4. Derzhstandart Ukrainy (1995) Derzhavnyi klasyfikator Ukrainy: Klasyfikator profesii DK 003-45 [State Classifier of Ukraine: Classifier of professions]. Kyiv: Derzhstandart Ukrainy.

5. Lazarieva, T.A. (2013) Vyrobnychi funktsii inzhenera-tekhnoloha kharchovoi haluzi yak osnova formuvannia zmistu tvorchoi profesiinoi pidhotovky [Production functions of the engineer-technologist of food industry as a basis of formation of the maintenance of creative professional training]. Pedagogical sciences: theory, history, innovative technologies, vol. 4 (30). pp. 237-246.

6. Lazarieva, T.A. (2014) Pidhotovka maibutnikh inzheneriv-tekhnolohiv kharchovoi haluzi do tvorchoi profesiinoi diialnosti: monohrafiia [Preparation of future engineers-technologists of food industry for creative professional activity: monograph]. Kharkiv: Pravo, $528 \mathrm{p}$.

7. Huzalova, O.V. (2010) Pedahohichni umovy orhanizatsii tvorchoi diialnosti studentiv vyshchykh tekhnichnykh navchalnykh zakladiv u protsesi vyvchennia pryrodnycho-matematychnykh dystsyplin: avtoref. dys. ... kand. ped. nauk: 13.00.04 [Pedagogical conditions for the organization of creative activity of students of higher technical educational institutions in the process of studying natural and mathematical disciplines] (PhD Thesis), Odesa.

8. Eremina, L.I., Nagornova, A.Yu., Nagornov, Yu.S. (2013) Tehnologii kreativnogo razvitiya studentov tehnicheskih spetsialnostey [Technologies for creative development of students of technical specialties] Fundamentalnyie issledovaniya, vol. 1. P. 78-81.

9. Nizovtsev, A.V. (2010) Formuvannia doslidnytskykh umin studentiv tekhnichnykh universytetiv u protsesi vyvchennia profesiino-oriientovanykh dystsyplin: avtoref. dys. ... kand. ped. nauk: 13.00.04. [Formation of research skills of students of technical universities in the process of studying professionally-oriented disciplines] (PhD Thesis), Poltava.

10. Popova, O.P. (2009) Rozvytok tvorchoho potentsialu maibutnoho inzhenera v protsesi profesiinoi pidhotovky u vyshchomu tekhnichnomu navchalnomu zakladi: avtoref. dys. .... kand. ped. nauk: 13.00.04. [Development of creative potential of the future engineer in the process of professional training in a higher technical educational institution] (PhD Thesis), Zaporizhzhia.

11. Lazarieva, T.A. (2015) Formuvannia profesiino vazhlyvykh yakostei tvorchoi diialnosti u maibutnikh inzheneriv-tekhnolohiv kharchovoi haluzi [Formation of professionally important qualities of creative activity in future engineers-technologists of food industry]. Problems of engineering and pedagogical education, vol. 46. P. 109-113.

12. Kozakov, V.A. (ed.) (2003) Psykholohiia diialnosti ta navchalnyi menedzhment [Psychology of activity and educational management], Kyiv: KNEU.

13. Shadrikov, V.D. (1996) Psihologiya deyatelnosti i sposobnosti cheloveka [Psychology of human activity and abilities], Moscow: Logos.

14. Kabanets, M.M. (2010) Pedahohichni umovy formuvannia u maibutnikh inzheneriv potreby u tvorchii samorealizatsii: avtoref. dys. ... kand. ped. nauk: 13.00.04. [Pedagogical conditions of formation of future engineers' need for creative self-realization] (PhD Thesis), Luhansk. 